\title{
Associations between Oral Hygiene Practice, Dietary Habits and $S$. mutans
}

\author{
Mai, $\mathrm{HY} Y^{1}, \mathrm{Wu}, \mathrm{CY}^{1,2}$, Chen SS ${ }^{1}$, Lin, BY ${ }^{1}, \mathrm{Chi}, \mathrm{LY}{ }^{1}$ \\ ${ }^{1}$ Department of Dentistry, National Yang Ming Chiao Tung University, Taiwan \\ ${ }^{2}$ Department of Periodontal Dentistry, Taipei Veterans General Hospital, Taiwan
}

Objectives: The average DMFT of 12-year-old schoolchildren in Taiwan in 2020 was 2.01, which was much higher than 1.00, the target set by the World Health Organization (WHO). In the past 20-30 years, the Taiwan government and dental teams have promoted many oral prevention policies, without detection of oral bacteria. This study explored the relationship between oral health and oral bacteria, and to see whether oral bacteria can be one of the indicators for predicting the risk of dental caries.

Materials and Methods: The study subjects were 13-18 years old students in Taipei metropolitan ( $N=320)$. The salivette was used for sampling, the Saliva DNA Kit was used to extract oral bacterial DNA, and using qPCR to measure the total bacterial count, S. mutans. The results of standardized oral examinations by dentists, the oral hygiene practices, dietary habits questionnaires, and the results of collected saliva analysis were cross-analyzed.

Results: The subjects of the study were junior and senior high school students in Taipei metropolitan ( $N=320)$, including 183 males $(57.19 \%$ ). The prevalence of dental caries was $73.8 \%$, mean DMFT was $3.36 \pm 3.46$, DT was $1.48 \pm 2.44$, MT was $0.04 \pm 0.34$, FT was $1.84 \pm 2.30$, S. mutans was $2.09 \pm 4.17$ fold change. The most important factors associated with DMFT: (1) Males are 0.21 less than females $(\mathrm{p}<0.001)$; (2) Senior school students were 0.27 higher than junior school students $(\mathrm{p}<0.001)$. The most important factor associated with quantity of oral $S$. mutans: Senior school students were 0.15 fold change higher than junior school students $(\mathrm{p}=0.01)$.

Conclusion: There are various factors associated with oral health. Analyzing oral bacteria in saliva can offer valuable information for predicting the risk of dental caries among adolescents in Taiwan.

Keywords: DMFT, Streptococcus mutans

Copyright (C) 2021. Korean Academy of Preventive Dentistry. All rights reserved.

This is an Open Access article distributed under the terms of the Creative Commons Attribution Non-Commercial License (http://creativecommons.org/licenses/ by-nc/4.0) which permits unrestricted non-commercial use, distribution, and reproduction in any medium, provided the original work is properly cited. 